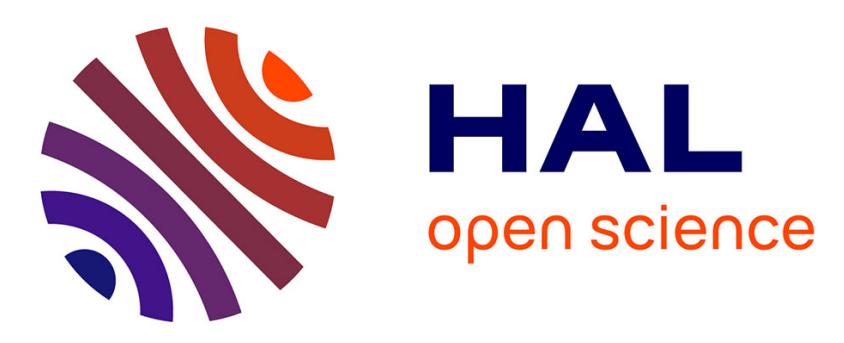

\title{
Ekbom's Syndrome or Real Ectoparasitosis? An Unexpected Outcome of Hidden Springtails
}

Guillaume Desoubeaux, Armand Saada, Éric Bailly, Claude Guiguen, Jacques Chandenier

\section{- To cite this version:}

Guillaume Desoubeaux, Armand Saada, Éric Bailly, Claude Guiguen, Jacques Chandenier. Ekbom's Syndrome or Real Ectoparasitosis? An Unexpected Outcome of Hidden Springtails. International Journal of Dermatology, 2014, 10.1111/j.1365-4632.2012.05631.x . hal-02443829

\section{HAL Id: hal-02443829 \\ https://hal.science/hal-02443829}

Submitted on 17 Jan 2020

HAL is a multi-disciplinary open access archive for the deposit and dissemination of scientific research documents, whether they are published or not. The documents may come from teaching and research institutions in France or abroad, or from public or private research centers.
L'archive ouverte pluridisciplinaire HAL, est destinée au dépôt et à la diffusion de documents scientifiques de niveau recherche, publiés ou non, émanant des établissements d'enseignement et de recherche français ou étrangers, des laboratoires publics ou privés. 


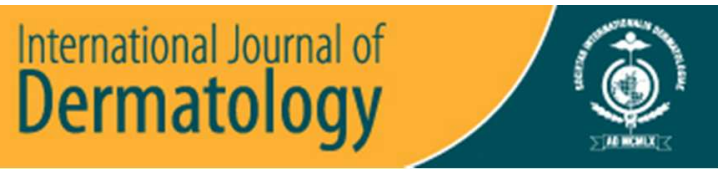

\section{Ekbom syndrome or real ectoparasitosis? The unexpected comeback of hidden springtails.}

\begin{tabular}{|r|l|}
\hline Journal: & International Journal of Dermatology \\
\hline Manuscript ID: & IJD-2011-1780 \\
\hline Manuscript Type: & Case Report \\
\hline Date Submitted by the Author: & 23-Dec-2011 \\
\hline Complete List of Authors: & $\begin{array}{l}\text { DESOUBEAUX, Guillaume; CHRU Bretonneau, Service de Parasitologie - } \\
\text { Mycologie - Médecine Tropicale; Unité INSERM U618, équipe 3a } \\
\text { Saada, Armand; CHRU Bretonneau, Service de Parasitologie - Mycologie - } \\
\text { Médecine Tropicale } \\
\text { BAILLY, Eric; CHRU Bretonneau, Service de Parasitologie - Mycologie - } \\
\text { Médecine Tropicale } \\
\text { Guiguen, Claude; CHRU Rennes, Laboratoire de Parasitologie - Mycologie } \\
\text { Chandenier, Jacques; CHRU Bretonneau, Service de Parasitologie - } \\
\text { Mycologie - Médecine Tropicale }\end{array}$ \\
\hline Keywords: & \begin{tabular}{l} 
parasitic disorders, insects, psychocutaneous medicine \\
\hline
\end{tabular} \\
\hline
\end{tabular}


1

2

3

4

5

6

\section{Ekbom syndrome or real ectoparasitosis? The unexpected comeback of hidden springtails.}

DESOUBEAUX Guillaume ${ }^{1}$, SAADA Armand ${ }^{1}$, BAILLY Eric ${ }^{1}$, GUIGUEN Claude ${ }^{2}$, CHANDENIER Jacques ${ }^{1}$.

${ }^{1}$ Department of Parasitology - Mycology - Tropical Medicine, Tours Hospital, FRANCE

${ }^{2}$ Laboratory of Parasitology - Mycology, Rennes Hospital, FRANCE

Corresponding author: guillaume.desoubeaux@univ-tours.fr

Author Contributions: Dr(s) Desoubeaux, Saada, Bailly, Guiguen, Chandenier had full access to all of the data in the study and take responsibility for the integrity of the data and the accuracy of the data analysis.

Study concept and design: Desoubeaux.

Acquisition of data: Desoubeaux, Saada, Chandenier.

Analysis and interpretation of data: Desoubeaux, Saada, Bailly, Guiguen, Chandenier.

Drafting of the manuscript: Desoubeaux.

Critical revision of the manuscript for important intellectual content: Desoubeaux.

Statistical analysis: none

Obtained funding: none

Administrative, technical, or material support: Desoubeaux, Chandenier.

Study supervision: Desoubeaux.

Financial disclosure should be divided as follows:

- Relationships relevant to this manuscript

- All other relationships 
Funding / Support: This study was supported by none.

Role of the Sponsors: The sponsors had no role in the design and conduct of the study; in the collection, analysis, and interpretation of data; or in the preparation, review, or approval of the manuscript.

Financial Disclosure: None reported

Acknowledgment: We are indebted to Frans Janssens (Department of Biology, University of Antwerp, Antwerp, B-2020, Belgium) for his precious advices for helping us in identification of the collembolan specimens.

Words count: 497

Number of references: 5

Number of figures and legends: 2

Abstract: We report here neuro-cutaneous case of delusional parasitosis involving atypical bugs called springtails or Collembola. Cases of springtails in association with Man are rare and often discussed by the scientific community.

This short clinical note focuses on the medical risk of diagnostic confusion arising from the accidental discover of bugs in human environment, especially when skin troubles are strongly reported. The importance of a right entomological identification avoids misdiagnosis and enables a better medical care.

Key words: delusional ectoparasitosis - Ekbom syndrome - arthropods - springtails - Collembola 
1

2

3

4

5

6

7

8

9

10

1 Ekbom syndrome or real ectoparasitosis? The unexpected comeback of hidden springtails.

2 DESOUBEAUX Guillaume ${ }^{1}$, SAADA Armand ${ }^{1}$, BAILLY Eric ${ }^{1}$, GUIGUEN Claude ${ }^{2}$, CHANDENIER Jacques ${ }^{1}$.

$3{ }^{1}$ Department of Parasitology - Mycology - Tropical Medicine, Tours Hospital, FRANCE

$4 \quad{ }^{2}$ Laboratory of Parasitology-Mycology, Rennes Hospital, FRANCE

$5 \quad$ Corresponding author: guillaume.desoubeaux@univ-tours.fr

6

7

8 Author Contributions: $\operatorname{Dr}(s)$ Desoubeaux, Saada, Bailly, Guiguen, Chandenier had full access to all of

9 the data in the study and take responsibility for the integrity of the data and the accuracy of the data 10 analysis.

11 Study concept and design: Desoubeaux.

12 Acquisition of data: Desoubeaux, Saada, Chandenier.

Analysis and interpretation of data: Desoubeaux, Saada, Bailly, Guiguen, Chandenier.

Drafting of the manuscript: Desoubeaux.

Critical revision of the manuscript for important intellectual content: Desoubeaux.

Statistical analysis: none

Obtained funding: none

Administrative, technical, or material support: Desoubeaux, Chandenier.

Study supervision: Desoubeaux.

Financial disclosure should be divided as follows:

- Relationships relevant to this manuscript

- All other relationships 
Funding / Support: This study was supported by none.

28

29

30

31

32

Role of the Sponsors: The sponsors had no role in the design and conduct of the study; in the collection, analysis, and interpretation of data; or in the preparation, review, or approval of the manuscript.

Financial Disclosure: None reported

Acknowledgment: We are indebted to Frans Janssens (Department of Biology, University of Antwerp, Antwerp, B-2020, Belgium) for his precious advices for helping us in identification of the collembolan specimens.

Words count: 497

\section{Number of references: 5}

Number of figures and legends: 2

Abstract: We report here neuro-cutaneous case of delusional parasitosis involving atypical bugs called springtails or Collembola. Cases of springtails in association with Man are rare and often discussed by the scientific community.

This short clinical note focuses on the medical risk of diagnostic confusion arising from the accidental discover of bugs in human environment, especially when skin troubles are strongly reported. The importance of a right entomological identification avoids misdiagnosis and enables a better medical care.

Key words: delusional ectoparasitosis - Ekbom syndrome - arthropods - springtails - Collembola 
An elderly couple had complained of skin disorders for a few months. The symptoms, described as

55

56

57

58

59

60

61

62

63

64

65

66

67

68

69

70

71

72

73

74

75

76

77

78

79

80

81

82

83

84

85

86

87

88

89

90

91

92 intensive pruritus, had never been explained despite multiple medical visits. None particular lesions had been noticed during these specialist examinations but individuals reported sensations of formication like bugs crawling on skin. They had already undergone many antihistaminic, anti-scabies or anxiolytic treatments, without convincing results. Both patients correlated the beginning of their troubles with the purchase of a new mattress. This latter had stayed in their cellar for many months before usage. One morning, the husband accidentally found a few bugs around his wife's body. He sent them to the department of Parasitology of Tours hospital for identification. This observation is obviously coherent with Collembolan specimens or springtails (Figure 1 and 2).

Springtails are ubiquitous saprophyte arthropods. They mainly feed on decaying vegetables or proliferating fungi like molds. They use to inhabit preferentially wet locals like fallen leafs, grass tufts, rotten wood, caves. As they participate to control microflora, they are indirectly involved in processing the organic matter in soil.

Springtails are usually considered as occasional pests of agricultural crops. However, they can exceptionally invade indoors where humidity rates are excessively high. Although this is totally inconsistent with their biological way of life, a few publications have suggested that springtails may become ectoparasites for humans (1). Unfortunately, such proofs haven't been scientifically provided yet (2) (3), in spite of their hairy body that may potentially cause pruritus in contact with skin (4). In our case, springtails were probably discovered by chance, close to the lady's person after she had spent the night sleeping on the new mattress. Previously, this one had been surely colonized during its long stay in the dark and wet cellar. So, this accidental finding should be rather considered as an authentic coincidence than the main cause of the skin disorders reported by the elderly couple.

Nevertheless, since they discovered the springtails, the patients became regrettably convinced of their responsibility, in spite of their saprophytic metabolism. In this context, recurrent complaints about skin disorders due to small bugs creeping under the skin should be preferentially considered as symptoms signing a psychiatric disease rather than a real entomological issue. These delusional parasitoses are described as Ekbom syndrome, a kind of psychosis related to a strong belief of being infested (5). Like in our case, such entities are not well known to non-specialists and consequently represent a risk of misdiagnosis, involving general practitioners, dermatologists, entomologists, pharmacists... Furthermore, ill people often express an insistent need of assistance. So, inadequate treatments are possibly overprescribed.

Springtails are highly sensitive to desiccation: the best way to get rid of them consists in aerating invaded rooms. Indeed, insecticides usage is thought to worsen the situation, because it enables springtails proliferation due to excessive punctual consuming of other dead bugs. Finally, in our case, we suggested to open all shutters of windows to dry up the indoor atmosphere. In theory, these recommended measures could eradicate springtails, but herein they especially allow appeasing the elderly psychotic patients. 
Figure 1: Example of a springtail specimen. This well-conserved arthropod is less than 0.14 inches long (nearly $3.5 \mathrm{~mm}$ ). It has a hairy-brown body with six legs inserted in the thorax. At the top of the head begins a couple of four-item segmented antenna (magnificence X25).

Figure 2: Another springtail specimen. This side view enables especially to observe the large ventral appendage called furcula, in the lowest part of the arthropod. Despite the rest of the specimen is quite altered, the different components of the body are easily recognizable (magnificence X25).

1. Altschuler DZ, Crutcher M, Dulceanu N, Cervantes BA, Terinte C, Sorkin LN. COLLEMBOLA (SPRINGTAILS) (ARTHROPODA: HEXAPODA: ENTOGNATHA) FOUND IN SCRAPINGS FROM INDIVIDUALS DIAGNOSED WITH DELUSORY PARASITOSIS. Journal of the New York Entomological Society. 2004 juin;112:87-95.

2. Christiansen KA, Bernard EC. Critique of the Article "Collembola (Springtails) (Arthropoda: Hexapoda: Entognatha) Found in Scrapings from Individuals Diagnosed with Delusory Parasitosis ». Entomological News. 2008 nov;119:537-40.

3. Lim CSH, Lim SL, Chew FT, Ong TC, Deharveng L. Collembola are unlikely to cause human dermatitis. J. Insect Sci. 2009;9:3.

4. Dasgupta R, Dasgupta B. Collembolan insects as potential parasites. Trans. R. Soc. Trop. Med. Hyg. 1990 juin;84(3):438.

5. Ekbom KA, Yorston G, Miesch M, Pleasance S, Rubbert S. The pre-senile delusion of infestation. Hist Psychiatry. 2003 juin;14(54 Pt 2):229-56. 
1

2

3

4

5

6

7

8

9

10

11

12

13

14

15

16

17

18

19

20

21

22

23

24

25

26

27

28

29

30

31

32

33

34

35

36

37

38

39

40

41

42

43

44

45

46

47

48

49

50

51

52

53

54

55

56

57

58

59

60

\section{Page 7 of 8 \\ International Journal of Dermatology}

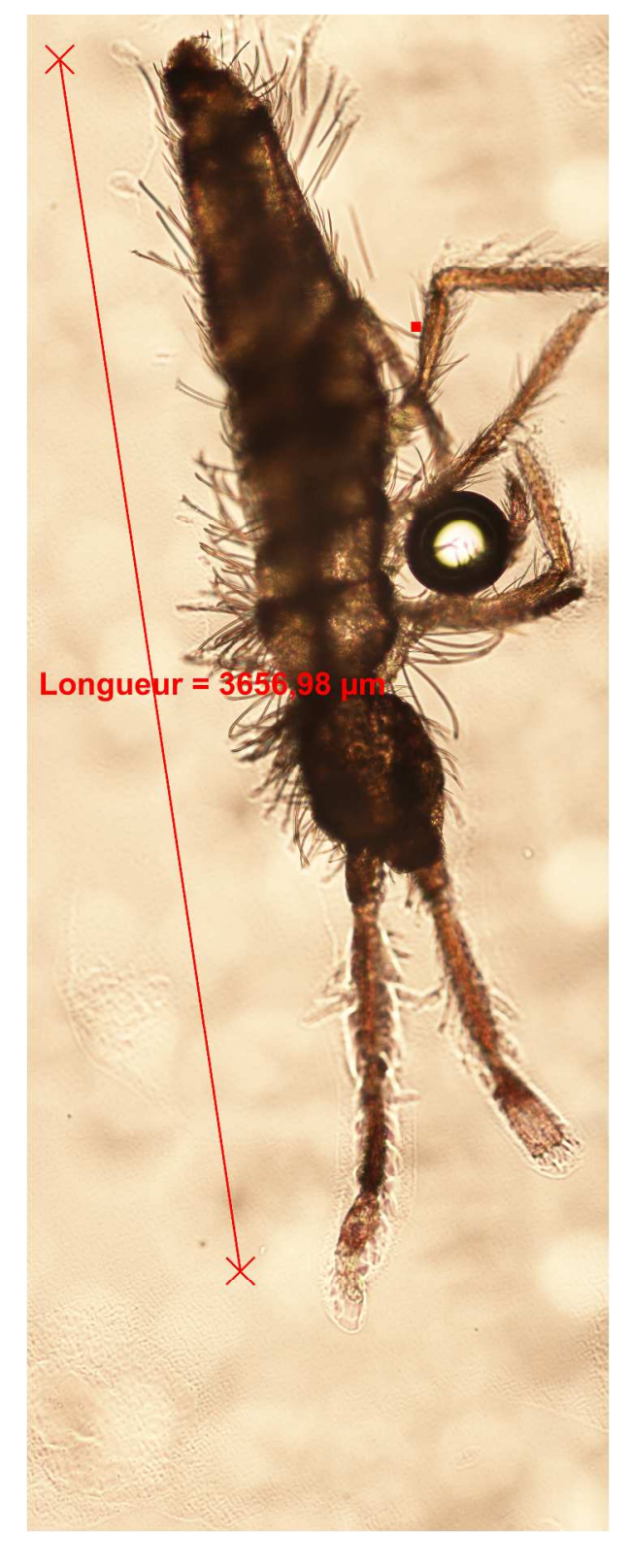

$417 \times 1088 \mathrm{~mm}(96 \times 96$ DPI)

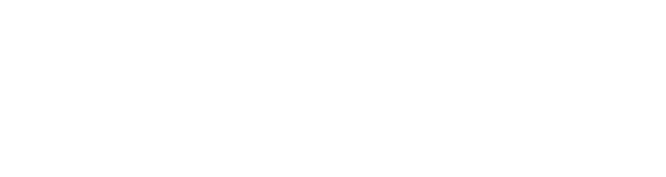




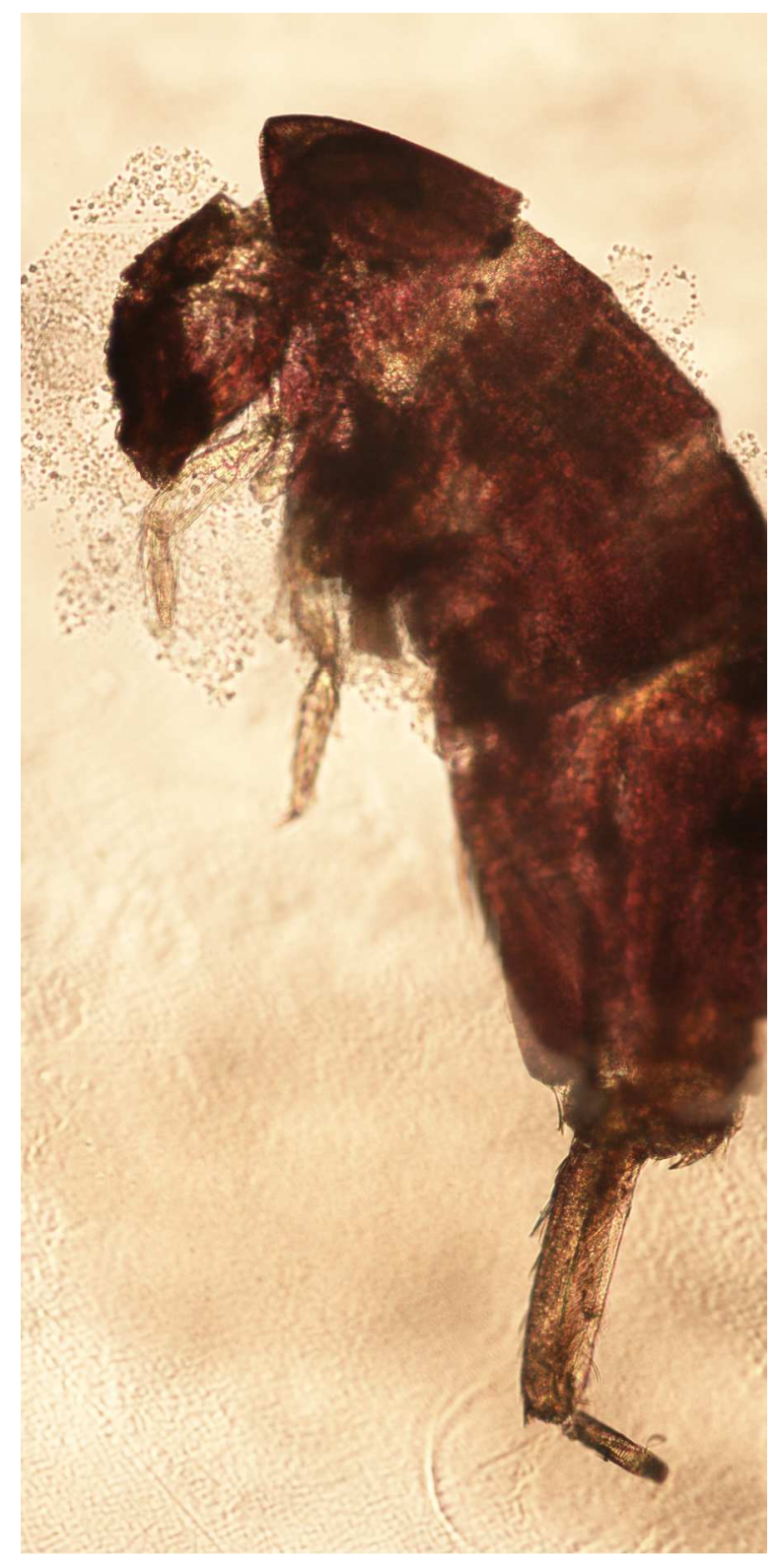

$363 \times 749 m m(96 \times 96$ DPI) 